\title{
THE INFLUENCE OF HIV-1 SUBTYPES C, CRF31_BC AND B ON DISEASE PROGRESSION AND INITIAL VIROLOGIC RESPONSE TO HAART IN A SOUTHERN BRAZILIAN COHORT
}

\author{
Cynara Carvalho NUNES(1), Maria Cristina Cotta MATTE(2), Claudia Fontoura DIAS(3), Leonardo Augusto Luvison ARAÚJO(2), \\ Luciano Santos Pinto GUIMARÃES(4), Sabrina ALMEIDA(2) \& Luis Fernando Macedo BRÍGIDO(5)
}

\begin{abstract}
SUMMARY
Background: Although most HIV-1 infections in Brazil are due to subtype B, Southern Brazil has a high prevalence of subtype $\mathrm{C}$ and recombinant forms, such as CRF31_BC. This study assessed the impact of viral diversity on clinical progression in a cohort of newly diagnosed HIV-positive patients. Methods: From July/2004 to December/2005, 135 HIV-infected patients were recruited. The partial pol region was subtyped by phylogeny. A generalized estimating equation (GEE) model was used to examine the relationship between viral subtype, CD4+ T cell count and viral load levels before antiretroviral therapy. Hazard ratio (Cox regression) was used to evaluate factors associated with viral suppression (viral load $<50$ copies/mL at six months). Results: Main HIV-1 subtypes included B (29.4\%), C (28.2\%), and CRF31_BC (23.5\%). Subtypes B and C showed a similar trend in CD4+ T cell decline. Comparison of non-B (C and CRF31_BC) and B subtypes revealed no significant difference in the proportion of patients with viral suppression at six months (week 24). Higher CD4+ T cell count and lower viral load were independently associated with viral suppression. Conclusion: No significant differences were found between subtypes; however, lower viral load and higher CD4+ T cell count before therapy were associated with better response.
\end{abstract}

KEYWORDS: HIV infections; CD4-positive T-lymphocytes; Viral load; Highly active antiretroviral therapy.

\section{INTRODUCTION}

According to the World Health Organization (WHO), 34.2 million people are currently living with HIV/AIDS in the world, with over eight million receiving antiretroviral (ARV) therapy ${ }^{17}$. Globally, most infections (almost 90\%) are due to recombinant or non-B subtype HIV-1 variants, whereas in developed nations subtype B prevails ${ }^{10}$.

In Brazil, according to data from the Epidemiological Bulletin of the Brazilian National Coordination on STD, AIDS and Viral Hepatitis, 594,917 accumulated cases of AIDS were reported from 1980 to $2010^{3}$. Along with preventive measures, early introduction of and free access to highly active antiretroviral therapy (HAART) have contributed to the relative control of the AIDS epidemic in Brazil, with increased survival and reduced AIDS-related morbidity and mortality. However, Rio Grande do Sul, the southernmost state of Brazil, despite having one of the best health care systems in the country, has the highest AIDS mortality rate, with 13.6 cases per 100,000 inhabitants. $^{3}$

Viral diversity is considered one of the potential determinants of viral pathogenesis and may impact treatment response ${ }^{14}$. Although most HIV-1 infections in Brazil are due to subtype B, southern Brazil is in a unusual situation: this region has a high prevalence of HIV-1 subtype $\mathrm{C}$ and $\mathrm{C}$ bearing recombinant forms $\mathrm{s}^{4}$. In a previous study conducted at our clinical research center, we documented the co-circulation of subtype C, subtype B and a recombinant form, CRF31_BC, present in a similar proportion of patients ${ }^{6}$. We believe that this epidemiological scenario provides a suitable environment to test the hypothesis that different viral variants are associated with different clinical progression of the disease and response to therapy. This study aimed to assess the impact of viral diversity on the clinical progression of a cohort of newly diagnosed HIV-positive patients starting follow-up at STD/AIDS Specialized Care Center of the Municipal Health Department (Public Health System) in the city of Porto Alegre, Southern Brazil.

\section{MATERIAL AND METHODS}

Study design: This prospective study was conducted at the STD/AIDS Specialized Care Center of the Municipal Health Department of Porto Alegre, city capital of Rio Grande do Sul, the southernmost state of Brazil. This is a municipally-owned institution that provides health services through the Brazilian public health system to patients from the city of Porto Alegre. The study was initiated in 2004 as part of the National HIV Vaccine Initiative within the Brazilian National STD/AIDS Program.

All authors declare no conflict of interest.

(1) Santa Marta Health Center, Municipal Health Department, Porto Alegre, RS, Brazil.

(2) Center for Scientific and Technological Development, State Foundation for Health Research and Production, Porto Alegre, RS, Brazil.

(3) STD/AIDS Specialized Care Center, Municipal Health Department, Porto Alegre, RS, Brazil.

(4) Department of Epidemiology and Biostatistics, Hospital de Clínicas de Porto Alegre, Porto Alegre, RS, Brazil.

(5) Adolfo Lutz Institute, São Paulo, SP, Brazil.

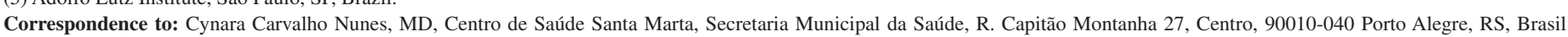

E-mail: cynara_infectologia@terra.com.br 
NUNES, C.C.; MATTE, M.C.C.; DIAS, C.F.; ARAÚJO, L.A.L.; GUIMARÃES, L.S.P.; ALMEIDA, S. \& BRÍGIDO, L.F.M. - The influence of HIV-1 subtypes C, CRF31_BC and B on disease progression and initial virologic response to HAART in a Southern Brazilian cohort. Rev. Inst. Med. Trop. Sao Paulo, 56(3): 205-11, 2014.

HIV-infected patients seeking medical care at our center between July 2004 and December 2005 were recruited for the study. Inclusion criteria were a) a recent serological diagnosis of HIV-1 infection (a positive HIV antibody test performed between 2004 and 2005), b) age > 17 years, c) no previous exposure to ARV drugs (ARV naïve individuals), and d) at least one measurement of viral load (VL) and CD4+ T/CD8+ $\mathrm{T}$ cell (CD4/CD8) counts before starting treatment. HIV serology was conducted using two enzyme immunoassays (EIAs), and concordantpositive seroconversion samples were confirmed by immunofluorescence (HIV-1 Immunofluorescence).

Clinical data were obtained from chart reviews and questionnaires. Eligible patients were followed up for approximately eight years after their inclusion in the study. HAART was defined as the combination of three or more drugs of at least two different classes: protease inhibitor (PI), nucleoside reverse transcriptase inhibitor (NRTI), or non-nucleoside reverse transcriptase inhibitor (NNRTI). In this study, we considered only the first-line therapy to evaluate clinical response to treatment.

Follow-up was part of routine clinical care, in which patients were assigned to undergo clinical and laboratory evaluations (including VL and CD4+ T cell counts) every three to six months before starting ARV treatment. After the initiation of HAART, clinical follow-up evaluations were scheduled every three months. Despite our efforts, we could not obtain all clinical measurements during the follow-up period because patients failed to attend scheduled follow-up visits or appointments for sample collection.

Baseline VL and CD4+ T cell counts were defined as the last measurement performed four months prior or up to one week after starting treatment. Pre-treatment CD4+ T cell counts were usually below 350 cells $/ \mathrm{mm}^{3}$, as at the time the study that was carried out was the recommended threshold established by the Brazilian Ministry of Health (www.aids.gov.br) to indicate ARV therapy. Viral suppression was defined as the first undetectable VL $(<50$ copies $/ \mathrm{mL})$.

Molecular analysis:HIV-1 subtyping was performed at the Adolfo Lutz Institute, São Paulo, SP, Brazil, or at the Center for Scientific and Technological Development, State Foundation for Health Research and Production, Porto Alegre, RS, Brazil. The partial pol region was amplified based on previously published protocols ${ }^{4}$. Briefly, polymerase chain reaction (PCR)-amplified DNA was sequenced using the ABI BigDye Terminator Cycle Sequencing Ready Reaction kit v.3.1 (Applied Biosystems, Foster City, CA, USA) and processed with an automated ABI 3100 Genetic Analyzer (Applied Biosystems). The sequences were assembled and edited using the Phred program (www.ial.sp.gov. br) followed by manual edition using SeqMan software (DNASTAR, Madison, WI, USA) or Sequencher (Genecodes, Ann Arbor, MI, USA). Subtypes were determined using the REGA HIV-1 subtyping tool (http://bioafrica.mrc.ac.za/subtypetool/html/subtyping.html). Moreover, the subtype was confirmed by sequence alignment with the reference sequence obtained from the HIV Sequence Database, Los Alamos National Laboratory (LANL; www.hiv.lanl.gov), to construct neighborjoining phylogenetic trees.

Viral load determination and CD4+ T cell count: VL was determined using branched-DNA (bDNA) technology (Siemens Diagnostics, Tarrytown, NY, USA) and CD4+ T/CD8+ T cell counts were obtained by flow cytometry (BD, Franklin Lakes, NJ, USA), both following the manufacturers' instructions and carried out at one of the local Laboratories of the National Network of CD4 and VL.

Ethical considerations: The study was approved by the Research Ethics Committee of the Municipal Health Department of Porto Alegre and Adolfo Lutz Institute, Brazil, and was conducted in accordance with the provisions of the Declaration of Helsinki. All participants provided written informed consent prior to their inclusion in the study.

Statistical analysis: Baseline characteristics among HIV-1 subtypes were analyzed using the chi-square test or Fisher's exact test for categorical variables, and analysis of variance (ANOVA) for continuous variables. The Kruskal-Wallis test was used to compare variables that did not have a normal distribution. Mann-Whitney test and Student's $t$ test were used to compare CD4+ T cell counts and VL between genders, respectively. CD4+ $\mathrm{T}$ cell counts and time were expressed as median and 25 th-75th interquartile range (IQR). VL results were transformed to and expressed as $\log _{10}$ values. A generalized estimating equation (GEE) model was used to examine the relationship between viral subtype and CD4+ T cell count and VL levels before therapy, as well as to compare CD4+ T cell count and VL levels between genders.

Post-HAART categorical variables were described both as absolute and relative frequencies. Quantitative variables were expressed as mean \pm standard deviation (SD) when they passed normality tests (e.g. Kolmogorov-Smirnov test) or as median and IQR when asymmetric. Values were considered to be statistically significant if $p$-value was < 0.05 . The association between different variables and viral suppression (VL $<50$ copies/mL at 24 weeks) was evaluated by using hazard ratio (HR) obtained from a Cox regression model. Only variables that reached statistical significance $(p<0.05)$ in the bivariate analysis were subsequently included in the multivariate analysis. All data were analyzed using the Statistical Package for the Social Sciences (SPSS) version 17.0 (IBM Corp., Armonk, NY, USA).

\section{RESULTS}

Study population: A total of $135 \mathrm{HIV}$-infected patients were initially selected for this study. The follow-up period was eight years, with a median follow-up of 24 months before HAART and 48 months after initiation of HAART. Pregnant women (14 cases) were excluded because they initiated ARV therapy to prevent mother-to-child transmission, regardless of CD4+ $\mathrm{T}$ cell counts or clinical disease as an indication for ARV therapy. HIV-1 subtype was determined for 85 subjects. The predominant strains comprised HIV-1 B (29.4\%), C (28.2\%), and CRF31_ BC (23.5\%); $18.8 \%$ accounted for subtype F or other recombinant forms, which were grouped together as they separately represented less than $5 \%$ of infections in this population.

The epidemiological, clinical and laboratory data of the 85 genotyped patients stratified by HIV-1 subtype are summarized in Table 1 . There were no significant differences between the subtypes regarding gender, age, ethnicity, sexual orientation, time from positive serology, and baseline VL and CD4+ T cell count.

Analysis of clinical characteristics before HAART: To evaluate the clinical course of HIV-infected patients (CD4+ T cell count and viral 


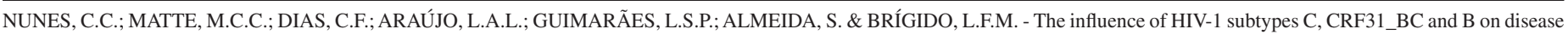
progression and initial virologic response to HAART in a Southern Brazilian cohort. Rev. Inst. Med. Trop. Sao Paulo, 56(3): $205-11,2014$.

Table 1

Demographic and clinical characteristics of the study population stratified by HIV-1 subtype

\begin{tabular}{|c|c|c|c|c|c|}
\hline & \multicolumn{4}{|c|}{ HIV-1 subtype } & \multirow[t]{2}{*}{$p^{*}$} \\
\hline & $\mathrm{B}(\mathrm{n}=25)$ & $C(n=24)$ & CRF31_BC $(\mathrm{n}=20)$ & F/URFs $(\mathrm{n}=16)$ & \\
\hline \multicolumn{6}{|l|}{ Gender } \\
\hline Male & $48(n=12)$ & $62.5(\mathrm{n}=15)$ & $65(n=13)$ & $37.5(n=6)$ & NS \\
\hline Female & $52(\mathrm{n}=13)$ & $37.5(\mathrm{n}=9)$ & $35(\mathrm{n}=7)$ & $62.5(\mathrm{n}=10)$ & \\
\hline Age (years) & $\begin{array}{l}44.11 \pm 10.92 \\
\quad(n=25)\end{array}$ & $\begin{array}{c}43.07 \pm 11.8 \\
(\mathrm{n}=24)\end{array}$ & $\begin{array}{l}41.98 \pm 8.55 \\
\quad(n=20)\end{array}$ & $\begin{array}{c}42.47 \pm 11.6 \\
(\mathrm{n}=16)\end{array}$ & $\mathrm{NS}$ \\
\hline \multicolumn{6}{|l|}{ Ethnicity } \\
\hline Caucasian origin & $76.2(\mathrm{n}=16)$ & $52.6(\mathrm{n}=10)$ & $62.5(\mathrm{n}=10)$ & $53.8(\mathrm{n}=7)$ & NS \\
\hline African origin & $9.5(\mathrm{n}=2)$ & $31.6(n=6)$ & $25(n=4)$ & $23.1(n=3)$ & \\
\hline Native origin & $14.3(\mathrm{n}=3)$ & $15.8(\mathrm{n}=3)$ & $12.5(\mathrm{n}=2)$ & $23.1(\mathrm{n}=3)$ & \\
\hline \multicolumn{6}{|l|}{ Sexual orientation } \\
\hline Heterosexual & $81(\mathrm{n}=17)$ & $89.5(\mathrm{n}=17)$ & $87.5(n=14)$ & $100(n=13)$ & NS \\
\hline MSM & $14.3(n=3)$ & $5.3(\mathrm{n}=1)$ & $6.3(n=1)$ & $0(\mathrm{n}=0)$ & \\
\hline Bisexual & $4.8(\mathrm{n}=1)$ & $5.3(\mathrm{n}=1)$ & $6.3(\mathrm{n}=1)$ & $0(\mathrm{n}=0)$ & \\
\hline $\begin{array}{l}\text { Time from first HIV antibody test } \\
\text { (months) }\end{array}$ & $\begin{array}{c}75.77(73.9-75.7) \\
(\mathrm{n}=23)\end{array}$ & $\begin{array}{c}75.26(70.6-79.3) \\
(\mathrm{n}=23)\end{array}$ & $\begin{array}{c}76.67(72.2-84.5) \\
(\mathrm{n}=17)\end{array}$ & $\begin{array}{c}76.82(70.5-78.0) \\
(\mathrm{n}=12)\end{array}$ & NS \\
\hline $\begin{array}{l}\text { Baseline viral load } \\
\left(\log _{10} \text { copies } / \mathrm{mL}\right)\end{array}$ & $\begin{array}{l}4.54 \pm 0.92 \\
(\mathrm{n}=25)\end{array}$ & $\begin{array}{l}4.65 \pm 0.68 \\
(\mathrm{n}=24)\end{array}$ & $\begin{array}{l}4.37 \pm 0.70 \\
(\mathrm{n}=18)\end{array}$ & $\begin{array}{l}4.15 \pm 0.97 \\
(\mathrm{n}=15)\end{array}$ & NS \\
\hline $\begin{array}{l}\text { Baseline CD4+ T cell count } \\
\left(\text { cells } / \mathbf{m m}^{3}\right)\end{array}$ & $\begin{array}{l}165(71-240) \\
\quad(\mathrm{n}=23)\end{array}$ & $\begin{array}{c}193(90-295) \\
\quad(\mathrm{n}=23)\end{array}$ & $\begin{array}{c}184(99-277) \\
\quad(\mathrm{n}=20)\end{array}$ & $\begin{array}{c}212(143-296) \\
\quad(\mathrm{n}=16)\end{array}$ & NS \\
\hline
\end{tabular}

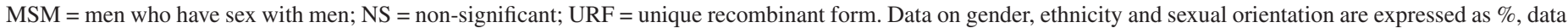

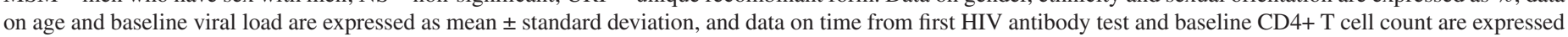
as median (interquartile range).

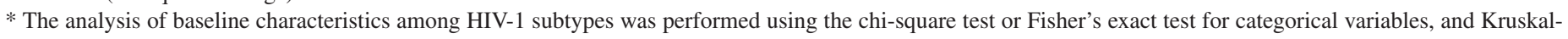
Wallis test or analysis of variance (ANOVA) for continuous variables. Values of $p<0.05$ were considered significant.

dynamics) over a one-year period, we considered three time points along the follow-up period: 24 months $\left(t_{24}\right)$ and 12 months $\left(t_{12}\right)$ before treatment and baseline measurement $\left(\mathrm{t}_{0}\right)$. For all patients included in the $\mathrm{t}_{24}$ measurement, median CD4+ $\mathrm{T}$ cell count was 367 (IQR 321-452) cells $/ \mathrm{mm}^{3}$ and VL was $3.86( \pm 0.66)$ copies $/ \mathrm{mL}$; at $\mathrm{t}_{12} \mathrm{CD} 4+\mathrm{T}$ cell count was 379 (IQR 277-498) cells $/ \mathrm{mm}^{3}$ and VL was 4.27 ( \pm 0.84$)$ copies $/ \mathrm{mL}$ (Table 2). A marked decrease was observed between $\mathrm{t}_{12}$ and $\mathrm{t}_{0}(48.68 \%)$, with median baseline CD4+ T cell counts of 194.5 (IQR 103.75-280.75) cells $/ \mathrm{mm}^{3}$. As for VL levels, two subsequent increases were observed between $t_{12}$ and $t_{0}$, as shown in Table 2 .

The same analysis was performed to assess differences between HIV1 subtypes in the clinical course of patients (Table 2). The subtypes B and $\mathrm{C}$ showed a similar trend in CD4+ T cell decline, with a marked reduction in CD4+ $\mathrm{T}$ cell counts at $\mathrm{t}_{0}$. The GEE analysis revealed no significant influence of HIV-1 subtype on CD4+ T cell count or VL levels. It is worth noting that samples analyzed at $\mathrm{t}_{24}$ were not necessarily the same samples analyzed at $\mathrm{t}_{12}$; therefore, the use of a GEE model allowed a more accurate analysis of these data. We also evaluated individual losses of CD4+ T cells per patient, which were calculated by subtracting the absolute number of baseline CD4+ T cells from the last absolute value detected, then dividing this value by the corresponding number of months within this interval.
We found a median loss of CD4+ T cells per month of 10.2 (IQR 6.9314.4) cells $/ \mathrm{mm}^{3}$. Considering a loss of up to 8 cells $/ \mathrm{mm}^{3}$ per month (up to 100 cells/year), we investigated a possible association between this reduction with age, gender and subtype (B vs. C/CRF31_BC), but no significant differences were found between these variables.

Overall, women showed a better clinical condition compared to men at baseline $\left(\mathrm{t}_{0}\right)$, with a median CD4+ T cell count of 165 (IQR 90-254) cells $/ \mathrm{mm}^{3}$ for men and 242 (IQR 167-304) cells $/ \mathrm{mm}^{3}$ for women $(p<0.001)$. Mean VL levels in the same time period were $4.6( \pm 0.85)$ copies $/ \mathrm{mL}$ for men, compared to $4.25( \pm 0.62)$ copies $/ \mathrm{mL}$ for women $(p=0.016)$.

Analysis of clinical characteristics after HAART: Overall, the rate of patients achieving an undetectable VL $(<50$ copies $/ \mathrm{mL})$ within 12 months after starting HAART was $100 \%$ for subtype B, $88.9 \%$ for C, and $92 \%$ for CRF31_BC. Subtype F/unique recombinant forms (URFs) were not included in this analysis because they separately represented less than $5 \%$ of infections in the study population. The median follow-up after HAART was 48 (IQR 28-60) months. In this study, we considered the initial response to treatment at week 24 (six months). There was no statistically significant difference between subtypes when the proportion 
NUNES, C.C.; MATTE, M.C.C.; DIAS, C.F.; ARAÚJO, L.A.L.; GUIMARÃES, L.S.P.; ALMEIDA, S. \& BRÍGIDO, L.F.M. - The influence of HIV-1 subtypes C, CRF31_BC and B on disease progression and initial virologic response to HAART in a Southern Brazilian cohort. Rev. Inst. Med. Trop. Sao Paulo, 56(3): 205-11, 2014.

Table 2

CD4+ T lymphocyte counts and viral load at different time points before initiation of HAART stratified by HIV-1 subtype

\begin{tabular}{|c|c|c|c|c|c|c|}
\hline & $t_{24}(n=22)$ & $t_{12}(n=22)$ & $\mathrm{t}_{0}(\mathrm{n}=126)$ & $\Delta_{1}$ & $\Delta_{2}$ & $\Delta \mathrm{t}$ \\
\hline \multicolumn{7}{|l|}{ Study population } \\
\hline $\mathrm{CD} 4+\mathrm{T}$ cell count $\left(\mathrm{cells} / \mathrm{mm}^{3}\right)$ & $367(321-451.5)$ & $379(276.5-497.5)$ & $194.5(103.75-280.75)$ & $3.27 \%$ & $-48.68 \%$ & $-47.0 \%$ \\
\hline Viral load ( $\log _{10}$ copies $\left./ \mathrm{mL}\right)$ & $3.88 \pm 0.67$ & $4.25 \pm 0.87$ & $4.43 \pm 0.77$ & $9.54 \%$ & $4.24 \%$ & $14.18 \%$ \\
\hline \multicolumn{7}{|l|}{ Subtype B } \\
\hline CD4+ T cell count $\left(\right.$ cells $\left./ \mathrm{mm}^{3}\right)$ & $320.5(274-367)$ & $474.5(190-688.5)$ & $165(71-240)$ & $48.05 \%$ & $-65.23 \%$ & $-48.52 \%$ \\
\hline Viral load $\left(\log _{10}\right.$ copies $\left./ \mathrm{mL}\right)$ & $3.72 \pm 0.69$ & $4.12 \pm 1.4$ & $4.54 \pm 0.93$ & $10.75 \%$ & $10.19 \%$ & $22.04 \%$ \\
\hline \multicolumn{7}{|l|}{ Subtype C } \\
\hline $\mathrm{CD} 4+\mathrm{T}$ cell count $\left(\mathrm{cells} / \mathrm{mm}^{3}\right)$ & $370(322-409)$ & $390.5(273-430.75)$ & $193(90-295)$ & $5.54 \%$ & $-50.58 \%$ & $-47.84 \%$ \\
\hline Viral load $\left(\log _{10}\right.$ copies $\left./ \mathrm{mL}\right)$ & $3.96 \pm 0.56$ & $4.09 \pm 1.15$ & $4.65 \pm 0.68$ & $3.28 \%$ & $13.69 \%$ & $17.42 \%$ \\
\hline \multicolumn{7}{|l|}{ CRF31_BC } \\
\hline $\mathrm{CD} 4+\mathrm{T}$ cell count $\left(\mathrm{cells} / \mathrm{mm}^{3}\right)$ & $424(334.5-475)$ & $349(249-524)$ & $182.5(99.25-276.75)$ & $-17.69 \%$ & $-47.71 \%$ & $-56.96 \%$ \\
\hline Viral load $\left(\log _{10}\right.$ copies $\left./ \mathrm{mL}\right)$ & $4.21 \pm 0.8$ & $4.29 \pm 0.85$ & $4.4 \pm 0.7$ & $1.90 \%$ & $2.6 \%$ & $4.51 \%$ \\
\hline \multicolumn{7}{|l|}{ Subtype F/URFs } \\
\hline CD4+ T cell count $\left(\right.$ cells $\left./ \mathrm{mm}^{3}\right)$ & $324(278.25-420.75)$ & $311.5(278-345)$ & $212(142.5-295.75)$ & $-3.85 \%$ & $-31.94 \%$ & $-34.57 \%$ \\
\hline Viral load ( $\log _{10}$ copies $\left./ \mathrm{mL}\right)$ & $3.74 \pm 0.36$ & $4.47 \pm 0.0$ & $4.11 \pm 0.95$ & $19.51 \%$ & $-8.05 \%$ & $9.09 \%$ \\
\hline
\end{tabular}

HAART = highly active antiretroviral therapy; $\mathrm{t}_{24}=$ measurement at 24 months before HAART; $\mathrm{t}_{12}=$ measurement at 12 months before HAART; $\mathrm{t}_{0}=$ baseline measurement at initiation of HAART; URF $=$ unique recombinant form. $\mathrm{CD} 4+\mathrm{T}$ cell count values are expressed as median (interquartile range) and viral load values are expressed as mean \pm standard deviation. $\Delta_{1}$ : Difference in CD4+ T and viral load levels between $\mathrm{t}_{24}$ and $\mathrm{t}_{12}$ calculated as $\left[\left(\mathrm{t}_{12}-\mathrm{t}_{24}\right) / \mathrm{t}_{24}\right] * 100 . \Delta_{2}:$ Difference in CD4+ T and viral load levels between $\mathrm{t}_{12}$ and $\mathrm{t}_{0}$ calculated as $\left[\left(\mathrm{t}_{0}-\mathrm{t}_{12}\right) / \mathrm{t}_{12}\right] * 100 . \Delta_{1}$ : Difference in CD4+ T and viral load levels between $\mathrm{t}_{24}$ and $\mathrm{t}_{0}$ calculated as $\left[\left(\mathrm{t}_{0}-\mathrm{t}_{24}\right) / \mathrm{t}_{24}\right) * 100$. Generalized estimating equation (GEE) analysis was used and no statistical difference was found between subtypes.

(\%) of patients with viral suppression at week 24 was assessed comparing non-B (C and CRF31_BC) vs. B subtype (univariate $\mathrm{HR}=0.8 ; 95 \% \mathrm{CI}$ $0.43-1.49 ; p=0.48)$.

We also analyzed a possible association of gender, age, baseline VL, CD4+ T cell count below or above 100 cells $/ \mathrm{mm}^{3}$, and use of PI or NNRTI with viral suppression at week 24 . Lower baseline VL, higher CD4+ T cell count and younger age were significantly associated with viral suppression at six months $(p<0.001, p=0.002$, and $p=0.032$, respectively). At adjusted $\mathrm{HR}$, only lower VL and higher CD4+ T cell count remained significantly associated with viral suppression at six months (Table 3).

The rate of CD4+ T cell count increased during the post-HAART follow-up period, and we can observe that the first three months were crucial for immunological recovery. Although individuals infected with subtype $C$ showed a higher median baseline CD4+ T cell count (193 cells $\left./ \mathrm{mm}^{3}\right)$ when compared to subtype B (165 cells $\left./ \mathrm{mm}^{3}\right), \mathrm{CD} 4+\mathrm{T}$ cell recovery at three months after starting therapy was more marked in subtype B $(56.4 \%)$ than in subtype C (18.13\%) (data not shown). Despite this initial difference between these two subtypes, this ratio was not maintained for an extended period ( 24 months). The GEE analysis revealed no significant differences in CD4+ T cell count recovery and VL levels between subtypes, age and gender.

\section{DISCUSSION}

Data from cohort studies of individuals living with HIV/AIDS in Brazil are very limited. This study reported on the clinical progression of a cohort of HIV-infected patients followed up at a public health unit in the largest city in Southern Brazil. A peculiar aspect of this unit is the fact that it provides care to people from a local community that comprises the highest proportion of patients infected with CRF31, a B/C recombinant form that has been detected in different parts of Southern Brazil $^{4}$ and that, in this health unit, reaches a proportion comparable to that of subtype B or C. ${ }^{6}$ The co-circulation of these three HIV variants, which are responsible for most local HIV infections, makes this health unit an ideal setting to study the impact of viral diversity on disease progression and response to HAART, also allowing investigation of biomedical preventive tools, such as vaccines.

The rather homogenous socioeconomic characteristics of the population investigated in this study strengthen the comparability of patients infected with different HIV-1 subtypes, a major drawback common to studies comparing populations that have different backgrounds, such as most studies conducted in Europe $e^{2,5,8,9}$, where patients infected with non-B subtypes are generally immigrants with ethnic and socioeconomic differences that introduce potential bias. In most of those studies, subtype segregation is associated with socioeconomic status, access to treatment, health status and other factors that may influence disease outcome. Studies conducted in Africa have allowed a better evaluation of this issue at the community level ${ }^{11}$. However, their circulating subtypes differ from those found in Brazil, as do ethnic-, social- and health-related issues.

In the present cohort, we assessed the decline in CD4+ T cell count before HAART and found no significant difference between subtypes C, CRF31_BC, and B. We also evaluated early (six months) response to ARV therapy, and no significant difference was observed between subtype B and non-B (C and CRF31_BC). However, younger age, lower 
NUNES, C.C.; MATTE, M.C.C.; DIAS, C.F.; ARAÚJO, L.A.L.; GUIMARÃES, L.S.P.; ALMEIDA, S. \& BRÍGIDO, L.F.M. - The influence of HIV-1 subtypes C, CRF31_BC and B on disease progression and initial virologic response to HAART in a Southern Brazilian cohort. Rev. Inst. Med. Trop. Sao Paulo, 56(3): 205-11, 2014

Table 3

Predictors of viral suppression (viral load $<50$ copies $/ \mathrm{mL}$ ) at week 24 (six months) after initiation of HAART

\begin{tabular}{|c|c|c|c|c|c|}
\hline & \multicolumn{5}{|c|}{ Cox regression analysis } \\
\hline & Week 24 & Crude HR (95\%CI) & $p$ & Adjusted HR (95\%CI) & $p$ \\
\hline \multicolumn{6}{|l|}{ Subtype $(\%)$ aviremic } \\
\hline $\mathrm{C}, \mathrm{CRF} 31$ & 77.4 & $0.8(0.43-1.49)$ & 0.483 & --- & \\
\hline B & 85.7 & ref & & --- & \\
\hline \multicolumn{6}{|l|}{ Gender $(\%)$ aviremic } \\
\hline Male & 75.9 & $0.65(0.36-1.21)$ & 0.174 & --- & \\
\hline Female & 87.0 & ref & & --- & \\
\hline \multicolumn{6}{|l|}{ HAART $(\%)$ aviremic } \\
\hline PI-based & 82.9 & $1.1(0.56-2.16)$ & 0.779 & --- & \\
\hline NNRTI-based & 75.0 & ref & & --- & \\
\hline \multicolumn{6}{|c|}{ CD4+ $\mathbf{T}$ cell count $(\%)$ aviremic } \\
\hline Above 100 cells $/ \mathrm{mm}^{3}$ & 86.5 & $3.5(1.57-7.90)$ & 0.002 & $2.406(1.012-5.720)$ & 0.047 \\
\hline Below 100 cells $/ \mathrm{mm}^{3}$ & 66.7 & ref & & & \\
\hline \multicolumn{6}{|l|}{ Age (mean \pm SD) } \\
\hline Aviremic & $42.3 \pm 10.7$ & $0.97(0.94-0.99)$ & 0.032 & $0.968(0.934-1.003)$ & 0.074 \\
\hline Viremic & $49.0 \pm 8.6$ & --- & & --- & \\
\hline \multicolumn{6}{|l|}{ Viral load [median (IQR)] } \\
\hline Aviremic & $4.3(3.9-5.0)$ & $0.44(0.28-0.70)$ & $<0.001$ & $0.525(0.306-0.901)$ & 0.019 \\
\hline Viremic & $5.1(4.6-5.6)$ & --- & & --- & \\
\hline
\end{tabular}

VL levels and a CD4+ T cell count above 100 cells $/ \mathrm{mm}^{3}$ were associated with a better response at six months. In the adjusted analysis, both CD4+ $\mathrm{T}$ cell count above 100 cells $/ \mathrm{mm}^{3}$ and lower VL remained significantly associated with a better response at six months after HAART.

The analysis of HIV disease progression before HAART revealed a major decrease in CD4+ T cell count during the last period without ARV therapy (last 12 months), since at the time this study was carried out a CD4+ T cell count below 350 cells $/ \mathrm{mm}^{3}$ was the threshold recommended by the Brazilian Ministry of Health to introduce ARV treatment. This is in agreement with the literature on the natural history of HIV infection, which suggests a greater decline of CD4+ T cells as the disease progresses ${ }^{1}$. Nevertheless, further studies addressing this issue will be increasingly difficult, as the guidelines for treatment have evolved to indicate treatment at higher CD4+ T cell counts. According to the 2013 Brazilian Guidelines, HAART must be started in patients with CD4+ T cell count below 500 cells $/ \mathrm{mm}^{3}$. Although we found no significant differences when subtypes were compared, a study of CD4+ T cell decline in subtype A, B, C and D infections found a significant four-fold faster rate of CD4+ $\mathrm{T}$ cell decline (after adjustment for gender, ethnicity and baseline CD4+ T cell count) for subtype D infections ${ }^{8}$. Another study assessing the rate of CD4+ T cell decline in 312 HIV-positive volunteers at the time of seroconversion in Rakai District, Uganda, reported that infection with subtype D was also associated with a greater decline in CD4+ T cells as compared to subtype $\mathrm{A}$ and recombinants ${ }^{11}$. It is possible that subtype $\mathrm{D}$ is a more pathogenic variant, but this subtype is rarely observed in Brazil.
Subtype B is the most common HIV-1 variant in industrialized countries. Therefore, ARV drug development has based a large part of its studies on HIV-1 B subtype, along with studies of therapy response and the emergence of resistance ${ }^{16}$. In our study, after 12 months of ARV therapy, $100 \%$ of patients infected with subtype B, $88.9 \%$ with $\mathrm{C}$ and 92\% with CRF31_BC reached a VL under 50 copies/mL. When HAART response at week 24 (six months) was considered, there was no difference in the rate of undetectable $\mathrm{VL}(<50$ copies $/ \mathrm{mL})$ for subtype B versus non-B (C and CRF31_BC). When other variables were considered, including gender, age, pre-treatment VL or CD4+ T cell counts, and use of PI in first-line ARV therapy, we observed an association of viral suppression with a higher CD4+ T cell count, lower VL, and younger age. After adjustment, CD4+ T cell count above 100 cells $/ \mathrm{mm}^{3}$ and lower median VL remained significant. In a London study, responses of subtypes A, B, C, D and CRF02_AG were evaluated, with $90 \%$ of patients presenting viral suppression. Patients infected with subtypes A and $C$ reached undetectable levels faster than those infected with subtype $\mathrm{B}^{8}$. Another cohort study conducted in the UK showed no significant differences in the initial response to HAART for subtypes A, B, C, D, and CRF02_AG9. A Brazilian study evaluated the response of HIV-1 subtypes $\mathrm{B}$ and $\mathrm{F}$ and concluded that HAART was equally effective against these subtypes $^{12}$. In a study in Spain, 79 ARV naïve patients of different ethnicities were evaluated as to the time to reach viral suppression and CD4+ T cell gain, with results suggesting a similar outcome for B and non-B subtypes ${ }^{5}$. A cohort study conducted in France also found a similar time to reach viral suppression in subtype $\mathrm{B}$ and non-B infected patients, 
NUNES, C.C.; MATTE, M.C.C.; DIAS, C.F.; ARAÚJO, L.A.L.; GUIMARÃES, L.S.P.; ALMEIDA, S. \& BRÍGIDO, L.F.M. - The influence of HIV-1 subtypes C, CRF31_BC and B on disease progression and initial virologic response to HAART in a Southern Brazilian cohort. Rev. Inst. Med. Trop. Sao Paulo, 56(3): 205-11, 2014.

and the adjusted analysis showed that a higher median VL was associated with a longer time to reach viral suppression. ${ }^{2}$

When CD4+ T cell increase was evaluated, we observed a faster CD4+ $\mathrm{T}$ cell gain in the first three months for all subtypes. A faster increase has been described for the initial treatment period ${ }^{13}$. After adjustment (GEE model), however, we observed no significant difference. In a study conducted in the UK, a similar CD4+ T cell recovery was also observed for subtypes A, B, C, D, and CRF02_AG. ${ }^{9}$

Although no differences were observed between subtypes in our study, we found a significant association of some parameters with gender, with women showing a significantly higher CD4+ T cell count and a significantly lower VL than men at baseline and during the pre-treatment period. A lower VL has been observed in women, especially in cases of a CD4+ T cell count higher than 350 cells $/ \mathrm{mm}^{3}{ }^{7}$, which was the case of most patients in this cohort. These CD4+ T cell differences might be attributed to the fact that men are likely to seek care later than women. In a study conducted in rural Zimbabwe, reasons such as manhood were reported as barriers that can hinder access to health services ${ }^{15}$. The conflict between local understandings of manhood and biopolitical representations of "a good patient" may provide a possible explanation to why so many men do not make use of HIV services in Zimbabwe as well as in other countries.

Our study has some limitations, including missing data and a small sample size. We initially planned to have a larger sample, which was not possible because the priorities of the Brazilian HIV Vaccine Initiative changed during the course of the study and the support was kept for two years only. However, although the sample size was small, calculation of the detectable difference for the primary outcome (viral suppression at week 24) demonstrated sufficient power for analysis. Therefore, the sample can be considered sufficient to detect significant differences, considering associations seen in other investigations. Despite its limitations, this study is the first to document the clinical course of subtype B, C and the Brazilian recombinant CRF31_BC, showing no major differences in clinical progression and therapy response. Also, this study showed that it is possible for a public organization to provide information on the AIDS epidemic, which may stimulate new efforts targeting the promotion of research in public health units. Nevertheless, investigations with longer follow-up and a larger population size are needed to detect small differences that may not have been observed in our study and to better elucidate the differential role of these variants, if any, in HIV pathogenesis.

\section{RESUMO}

\section{A influência dos subtipos C, CRF31_BC e B do vírus HIV-1 na progressão da infecção e resposta virológica inicial a terapia antirretroviral em uma coorte no sul do Brasil}

Introdução: Embora a maioria das infecções de HIV-1 no Brasil seja devido ao subtipo B, o Sul do Brasil apresenta uma alta prevalência do subtipo $\mathrm{C}$ e formas recombinantes, como CRF31_BC. Este estudo avaliou o impacto da diversidade viral na evolução clínica em uma coorte de pacientes HIV-positivos recém diagnosticados. Métodos: De julho/2004 a dezembro/2005, 135 pacientes anti-HIV reagentes foram recrutados. A região pol parcial foi subtipada por filogenia. Um modelo de equação de estimativa generalizada (GEE) foi utilizado para examinar a relação entre subtipo viral, contagem de células CD4 e níveis de carga viral pré-terapia antirretroviral. Hazard ratio (regressão de Cox) foi utilizada para avaliar os fatores associados à supressão viral (carga viral < 50 cópias/mL em seis meses). Resultados: Os principais subtipos de HIV-1 incluíram B (29,4\%), C (28,2\%) e CRF31_BC (23,5\%). Os subtipos B e C apresentaram uma tendência semelhante no declínio de células CD4. Quando comparados os subtipos não B (C e CRF31_BC) e $B$, não houve diferença significativa na proporção de pacientes com supressão viral aos seis meses (24 semanas). CD4 mais alto e carga viral mais baixa demonstraram associação independente com supressão viral. Conclusão: Não houve diferença significativa entre os subtipos; entretanto, viremia mais baixa e CD4 mais alto pré-terapia mostraram associação com melhor resposta.

\section{ACKNOWLEDGEMENTS}

We are grateful to Claudia Fontoura Vidal for assistance with the questionnaire review, to Daniela Benzano with statistical analyses, and to the team of Laboratório Centro de Saúde Vila dos Comerciários. This study was partially supported by a grant from the Brazilian Ministry of Health - AIDS Department.

\section{REFERENCES}

1. Bartlett JG, Gallant JE, editors. Medical management of HIV infection. Baltimore: Johns Hopkins University Press; 2005

2. Bocket L, Cheret A, Deuffic-Burban S, Choisy P, Gerard Y, de la Tribonnière X, et al. Impact of human immunodeficiency virus type 1 subtype on first-line antiretroviral therapy effectiveness. Antivir Ther. 2005;10:247-54.

3. Boletim Epidemiológico - AIDS e DST. Ano VIII, $\mathrm{n}^{\circ}$ 1. [Internet]. Brasilia: Departamento de DST, AIDS e Hepatites Virais; 2012 [cited 2013 June 01]. Available from: http://www.aids.gov.br/sites/default/files/anexos/publicacao/2011/50652/boletim aids_2011_final_m_pdf_26659.pdf

4. Brígido LF, Nunes CC, Oliveira CM, Knoll RK, Ferreira JL, Freitas CA, et al. HIV type 1 subtype $\mathrm{C}$ and $\mathrm{CB}$ Pol recombinants prevail at the cities with the highest AIDS prevalence rate in Brazil. AIDS Res Hum Retroviruses. 2007;23:1579-86.

5. de Arellano ER, Benito JM, Soriano V, López M, Holguín A. Impact of ethnicity and HIV type 1 subtype on response to first-line antiretroviral therapy. AIDS Res Hum Retroviruses. 2007;23:891-4.

6. Dias CF, Nunes CC, Freitas IO, Lamego IS, Oliveira IM, Gilli S, et al. High prevalence and association of HIV-1 non-B subtype with specific sexual transmission risk among antiretroviral naïve patients in Porto Alegre, RS, Brazil. Rev Inst Med Trop Sao Paulo. 2009;51:191-6.

7. Donnelly CA, Bartley LM, Ghani AC, Le Fevre AM, Kwong GP, Cowling BJ, et al. Gender difference in HIV-1 RNA viral loads. HIV Med. 2005;6:170-8.

8. Easterbrook PJ, Smith M, Mullen J, O'Shea S, Chrystie I, de Ruiter A, et al. Impact of HIV-1 viral subtype on disease progression and response to antiretroviral therapy. J Int AIDS Soc. 2010;13:4.

9. Geretti AM, Harrison L, Green H, Sabin C, Hill T, Fearnhill E, et al. Effect of HIV-1 subtype on virologic and immunologic response to starting highly active antiretroviral therapy. Clin Infect Dis. 2009;48:1296-305.

10. Hemelaar J, Gouws E, Ghys PD, Osmanov S; WHO-UNAIDS Network for HIV Isolation and Characterisation. Global trends in molecular epidemiology of HIV-1 during 2000-2007. AIDS. 2011;25:679-89. 
NUNES, C.C.; MATTE, M.C.C.; DIAS, C.F.; ARAÚJO, L.A.L.; GUIMARÃES, L.S.P.; ALMEIDA, S. \& BRÍGIDO, L.F.M. - The influence of HIV-1 subtypes C, CRF31_BC and B on disease progression and initial virologic response to HAART in a Southern Brazilian cohort. Rev. Inst. Med. Trop. Sao Paulo, 56(3): 205-11, 2014.

11. Kiwanuka N, Robb M, Laeyendecker O, Kigozi G, Wabwire-Mangen F, Makumbi FE, et al. HIV-1 viral subtype differences in the rate of CD4+ T-cell decline among HIV seroincident antiretroviral naive persons in Rakai district, Uganda. J Acquir Immune Defic Syndr. 2010;54:180-4.

12. Lacerda HR, Medeiros LB, Cavalcanti AM, Ximenes RA, Albuquerque M de F. Comparison of the epidemiology, profile of mutations, and clinical response to antiretrovirals among subtypes $\mathrm{B}$ and $\mathrm{F}$ of the human immunodeficiency virus type 1. Mem Inst Oswaldo Cruz. 2007;102:693-9.

13. Lifson AR, Krantz EM, Eberly LE, Dolan MJ, Marconi VC, Weintrob AC, et al. Longterm CD4+ lymphocyte response following HAART initiation in a U.S. Military prospective cohort. AIDS Res Ther. 2011;8:2.

15. Skovdal M, Campbell C, Madanhire C, Mupambireyi Z, Nyamukapa C, Gregson S Masculinity as a barrier to men's use of HIV services in Zimbabwe. Global Health. 2011;7:13.

16. Taylor BS, Sobieszczyk ME, McCutchan FE, Hammer SM. The challenge of HIV-1 subtype diversity. N Engl J Med. 2008;358:1590-602.

17. UNAIDS. Data and Analysis [Internet]. United Nations; 2013. [cited 2013 June 01]. Available from: http://www.unaids.org/en/dataanalysis/

Received: 23 June 2013

Accepted: 21 October 2013

14. Ndung'u T, Weiss RA. On HIV diversity. AIDS. 2012;26:1255-60. 